Original Research

\title{
The Influence of Web-Based Spiritual Problem Solving on the Prevention of Suicidal Risk among University Students
}

\author{
Siti Khadijah', Ah. Yusuf², Hanik Endang Nihayati², and Esti Yunitasari² \\ 1Politeknik Kesehatan Kemenkes Surakarta, Surakarta, Indonesia \\ ${ }^{2}$ Faculty of Nursing, Universitas Airlangga, Surabaya, Indonesia
}

\section{ABSTRACT}

Introduction: Suicide is a health phenomenon that is currently increasing, especially in young adults aged 15-29 years. The spiritual aspect in the form of belief in God is one way to prevent suicide. This study was conducted to determine the effect of web-based spiritual problem solving on the prevention of suicide risk in college students.

Methods: The research design used a pre-experimental one-group pre-posttest. The sample was 59 respondents using the purposive sampling technique. The independent variable was web-based spiritual problem solving, and the dependent variable was suicide risk prevention. The intervention was delivered via the web using PowerPoint media, inspirational videos, and counselling for approximately one month with four sessions. Data were collected using a questionnaire and analysed using the Wilcoxon sign rank test.

Results: Web-Based Spiritual Problem Solving significantly decreases suicide risk with a p-value of $0.000(\mathrm{p}<0.05)$.

Conclusion: Web-Based Spiritual Problem Solving has been shown to be effective in reducing students' suicide risk. This web intervention can be used for 24 hours and specifically for counselling and two-way communication on the web; privacy is maintained because of a hidden identity, which is seen in code when interacting with counsellors so as to minimize stigma.

\section{ARTICLE HISTORY}

Received: January 4, 2021

Accepted: November 2, 2021

\section{KEYWORDS}

Spiritual Problem Solving WebBased; Suicide Risk Prevention; College Students

\section{CONTACT}

Siti Khadijah

\$s.khadijah3029@gmail.com

$\doteq$ Politeknik Kesehatan Kemenkes Surakarta, Surakarta, Indonesia

Cite this as: Khadijah, S., Yusuf, Ah., Nihayati, H. E., Yunitasari, E., \& Tristiana, R. D. (2021). The Influence of Web-Based Spiritual Problem Solving on the Prevention of Suicidal Risk among University Students. Jurnal Ners, 16(2). 142-147. doi: $\underline{\text { http://dx.doi.org/10.20473/in.v16i2.23921 }}$

\section{INTRODUCTION}

Suicide is a phenomenon of increasing health problems among young adults aged 15-29 years. Suicide cases often appear in media coverage (Kementerian Kesehatan Republik Indonesia, 2019). Suicide is the leading cause of morbidity and mortality worldwide (Ballesteros \& Hilliard, 2016). That there is an increasing need for mental health in US Colleges, as many as $35 \%$ of college students report "feeling so depressed and having difficulty learning and another 50\% experiencing intense anxiety that makes it difficult to succeed academically, according to the Center for Collegiate Mental Health (CCMH) counselling., It was found that from 263 universities, 33\% had serious mental health problems and were accompanied by suicidal ideation (Tsong et al., 2018). A person's inability to control stress will lead to suicidal behaviour (Keliat \&
Pasaribu, 2016). The suicide death rate in Indonesia was higher in 2016 by 100,000 population, men $4.8 / 100,000$ higher than women by $2.0 / 100,000$ population (Kementrian Kesehatan Republik Indonesia, 2019).

Students are a group of young adults entering their early adulthood who will experience a period of challenges, rewards, and crises (Potter \& Perry, 2005). The life challenges and responsibilities that a person feels when approaching adulthood will be heavier, especially when entering the phase of being a student, the number of tasks and the perceived pressure will affect mental health. In 2019 a university student in Surakarta committed suicide (Ryantono, 2019). A preliminary study on students at Surakarta health college in 2019 revealed that the idea of suicide occurred highly in 32\% students, and was lower in $68 \%$ of students. The results of researcher interviews indicates there were problems 
with consulting students as some did not want to meet directly but only wanted to go through WhatsApp communication due to embarrassment, students blamed and were disappointed in God for the problems experienced. This needs to get serious attention so that preventative efforts can be made so that no suicide occurs. College students as the nation's next-generation must be aware of the potential risk of suicide that exists in themselves and it is increasingly important for universities to provide prevention and intervention programmes in the campus environment (Tsong et al., 2018). A study by Wolitzky-Taylor et al. (2019) described a metaanalysis that revealed that suicide data programmes were effective in University suicides.

Spiritual factors are part of the internal protective factors that are easier to modify so that problemsolving efforts can be done by reinforcing aspects. Spiritual (belief) is one way to prevent suicide. The online world can be used as a means to help lecturers provide guidance to counsellors to counsel. Counselling is not only done face-to-face (FTF) in one closed space, but can be done through a remote format assisted by technology which is further known as e-counselling (Hidayat, 2018). The use of the internet and social media is very high in college students as a repository to find solutions to solving mental health problems while maintaining privacy, reducing stigma, and efficiency of distance and time, so it is necessary to make facilities in the form of webbased spiritual problem-solving. This web-based spiritual problem solving is an effort to overcome obstacles with focused thought to find solutions by pouring out the spiritual aspect, namely belief by interpreting life problems and life goals through online networks. Web-based spiritual problem solving with the Watson approach that links healing roots, caring, and spirituality in nursing will be very important. Belief systems can affect clients emotionally, physically, psychologically, and behaviourally (O'Brien et al., 2013). Mcauliffe, Mcleavey, and Fitzgerald (2014) explained that problem-solving skills training provided significant psychological and social improvements, showed a positive treatment effect in the self-harm group.

Based on the phenomenon of problems above, this study is needed to analyse the effect of Web-Based Spiritual Problem Solving on the prevention of suicide risk in college students.

\section{MATERIALS AND METHODS}

This study used a pre-experimental design of one group pre-post-test. Before the research was carried out informed consent was gained from respondents. The study was conducted between March and June 2020. The population was 359 college students at the Health College in Surakarta. The total sample was 59 respondents obtained by purposive sampling with inclusion criteria: 1) regular students; 2) young adults aged 17-29 years; and 3) college students with positive screening results at high risk of suicide, screening using the Suicide Behavior QuestionnaireRevision (SBQ-R). The independent variable is webbased spiritual problem solving, and the dependent variable is the prevention of suicide risk. The risk of suicide was measured using the SBQ-R, which has four total score items. The total score was obtained by accumulating the individual item scores with total score ranges from 3 to 18 points. A total score of $\geq 7$ indicates a high risk of suicidal behaviour, while the $<7$ indicates a low risk of suicidal behaviour (Osman et al., 2001). The instrument has been tested for validity and reliability using Cronbach alpha with a value of 0.785 . The validity test was conducted in November 2019 by first testing the questionnaire on a number of 30 respondents who were not study subjects and who had the same characteristics as the study subjects.

The intervention was delivered via the web using PowerPoints, inspirational videos, and counselling for approximately one month with four sessions. The web can be used for 24 hours and specifically for counselling, the contract is made in advance according to the agreement with the counsellor so that two-way communication can occur. This research was in collaboration with an IT Consultant from the Institute of Phicos Group Surakarta so that there was a letter of agreement to maintain the privacy and security of respondents' data. During the counselling process, the data that appears on the consultation screen is only a student numeric code so that the counsellor will not know the identity of who was communicating with the counsellor. This was done to maintain the privacy of respondents. The investigators explained the research process to the respondents and provided guidance books on the use of spiritual problem-solving web to students, respondents fill out informed consent through the web by choosing willing or unwilling choice.

The first step was session 1, pre-test by filling out assessment questionnaire links on the web. The second step was session 2 , intervention with the web problem solving media using PowerPoint system and inspirational video which tells an inspiring story in the face of problems. The third step was session 3, two-way counselling with a counsellor. The fourth step was session 4 , an evaluation.

A two-way solution was conducted with the counsellor and filling in the post-test by filling in from the web system. The evaluation was carried out 1 week after counselling. The time allotted for two-way counselling was 60-90 minutes. Counselling was done online based on the web. Respondents were not identified because they appeared on the web as a code to reduce stigma and students willing to seek mental health help through the web can get the problems solved.

Ethical clearance for this research was carried out at the ethics committee at the Faculty of Nursing, Airlangga University on December 9, 2019, with certificate number 1854-KEPK. Before the data collection, the respondents were given informed consent which indicated the purpose of the study, the 
potential benefits and harm of the research, and ensures their complete anonymity throughout the research profess, and that they have the freedom to withdraw from the study at any time. After the informed consent distribution, the respondents were asked to sign it signifying the respondent's voluntary decision to be part of the study. The researcher addressed issues such as confidentiality, anonymity, and privacy. Further, the completed questionnaires are stored on the web and can only be accessed by IT admins.

\section{RESULTS}

Based on Table 1, some college students at Surakarta Health College had a positive risk of suicide $(n=59$, $16 \%$ ). The response rate was $85 \%$. For the positive risk group totaling 59 college students, the majority of respondents were women $(93.2 \%)$, at the second semester (first-year students; $37.3 \%$ ), aged 20 years old, (27.1\%), having physical or sexual abuse experience (3.4\%), and preferring to keep their problem alone $(45.8 \%)$.

Based on Table 2 and on the indicators of risk of suicide, there is a change for the better, the majority think that the desire to try suicide is a pre-test, the mind only passes it to be better during the post-test, that is, there is never any thoughts of suicide, for the frequency of suicidal thoughts in the pre-test year, the majority is rare ( 1 time) to change for the better during the post-test, namely never.

Based on Table 3, the study found a high risk of suicide pre-test $98.3 \%$ to $40.7 \%$. This shows that after being given a web-based problem-solving spiritual intervention the risk of suicide has decreased. The results of the study were carried out by the Wilcoxon test because the data were not normally distributed, the Wilcoxon test results were different or there was a significant effect between the risk of pre and post suicide carried out by web-based spiritual problemsolving interventions with a p-value of 0.000 (p < 0.05).

The Wilcoxon test results on the variable risk of suicide produced a $Z$-Value of $-4,676$ with $p=0.000$. It shows the value of significance was lower than level of significance $(a=5 \%$ or 0.05$)$. So, it can be concluded that there is a significant difference in the results of the risk of suicide at the pre-test and posttest. This means that there is an influence of webbased spiritual problem solving on the ability to prevent student suicide risk.

\section{DISCUSSION}

Based on the results of the screening the risk of suicide was measured using the SBQ-R, the positive prevalence of student suicide risk at the Surakarta Health College was $16 \%$ of the total respondents, with the highest demographic character in first-year students. They have a higher risk of suicide than those with second-year students or above because they are new students and are still in the transition period from late adolescence to early adulthood, learning
Table 1. Respondents' Characteristics ( $\mathrm{N}=59$ )

\begin{tabular}{lcc} 
Characteristics & $\mathbf{n}$ & $\mathbf{\%}$ \\
\hline Semester & 22 & 37.3 \\
2 & 9 & 15.3 \\
4 & 21 & 35.6 \\
6 & 7 & 11.9 \\
8 & & \\
Age (years old) & 1 & 1.7 \\
17 & 12 & 20.3 \\
18 & 13 & 22.0 \\
19 & 16 & 27.1 \\
20 & 13 & 22.0 \\
21 & 3 & 5.1 \\
22 & 1 & 1.7 \\
23 & & \\
Gender & 4 & 6.8 \\
Male & 55 & 93.2 \\
Women & & \\
Response to problems & 21 & 35.6 \\
Talk to friends & 27 & 45.8 \\
Keep it alone & 1 & 1.7 \\
Talk to family & 2 & 3,4 \\
Talk to friends \& kept alone & 2 & 3,4 \\
Talk to friends \& family & 4 & 6.8 \\
Keep alone, talk to friends \& family & & \\
History of Physical/Sexual Violence & 2 & 3,4 \\
Yes & 57 & 96.6 \\
Not & &
\end{tabular}

methods that are different from high school education, greater responsibility, and the period of adaptation to lectures cause them to have higher stress levels. Meanwhile, the students above are stronger because they have adapted and are psychologically mature. Even though the positive number is only $16 \%$, it is very important to note because it can have serious consequences for them.

Research results from Lu, Bian, and Song (2015) explains that mental health problems such as anxiety, depression and suicidal thoughts often occur in new students (Pieter \& Lubis, 2017). The psychological hazards in early adulthood, both personally and socially, stems from a failure in development that leaves them immature compared to other adults. Some of the factors that hinder this development include physical health barriers, parents who are overprotective of their children, and the influence of associations or peers.

The age range of college students who were positive for the risk of suicide was 17-23 years and most occurred at the age of 20 years. This contradicts the theory of Yusuf, Fitriyasari, R, and Nihayati (2015), that the risk factors for suicide in adolescents and those aged up to 45 years have a higher risk than those aged 25-45 years and 12 years. Today's young adult groups face greater challenges than the previous era, this is due to the very rapid development of science and technology, one of which is social media, which can influence their attitudes and behaviour, including suicidal behaviour. Putri (2018), Dr. Nova Riyanti Yusuf, SpKj from the 
Table 2. The Pre and Post-Test Suicide Risk Scores

\begin{tabular}{|c|c|c|c|c|}
\hline \multirow{2}{*}{ Indicator } & \multicolumn{2}{|c|}{ Pre-test } & \multicolumn{2}{|c|}{ Post-test } \\
\hline & $\mathbf{n}$ & $\%$ & $\mathbf{n}$ & $\%$ \\
\hline \multicolumn{5}{|l|}{ Thinking of trying to kill yourself } \\
\hline Never & 0 & 0.0 & 17 & 28.8 \\
\hline Only thoughts pass by & 39 & 66.1 & 32 & 54.2 \\
\hline Have a plan & 18 & 30.5 & 8 & 13.6 \\
\hline Has attempted suicide & 2 & 3,4 & 2 & 3,4 \\
\hline \multicolumn{5}{|c|}{ Frequency of suicidal thoughts in a year } \\
\hline Never & 2 & 3,4 & 19 & 32.2 \\
\hline Rarely $(1 \mathrm{x})$ & 28 & 47.5 & 22 & 37.3 \\
\hline Sometimes $(2 \mathrm{x})$ & 19 & 32.2 & 13 & 22.0 \\
\hline Often $(3-4 x)$ & 4 & 6.8 & 3 & 5.1 \\
\hline Very often $(\geq 5 \mathrm{x})$ & 6 & 10.2 & 2 & 3,4 \\
\hline \multicolumn{5}{|c|}{ Have told someone else that you wanted to kill yourself } \\
\hline None & 34 & 57.6 & 38 & 64.4 \\
\hline Yes, at one time & 21 & 35.6 & 20 & 33.9 \\
\hline Yes, more than $1 \mathrm{x}$ & 4 & 6.8 & 1 & 1.7 \\
\hline \multicolumn{5}{|c|}{ How big will it be to try to kill yourself one day } \\
\hline Never & 5 & 8.5 & 31 & 52.5 \\
\hline No way at all & 7 & 11.9 & 6 & 10.2 \\
\hline More than impossible & 6 & 10.2 & 3 & 5.1 \\
\hline Impossible & 28 & 47.5 & 9 & 15.3 \\
\hline Maybe & 1 & 18.6 & 0 & 15.3 \\
\hline More than possible & 1 & 1.7 & 1 & 0.0 \\
\hline Very likely & 1 & 1.7 & 1 & 1.7 \\
\hline
\end{tabular}

Table 3. Wilcoxon Test Statistics for Student Suicide Risk (N = 59)

\begin{tabular}{ccccc}
\hline \multirow{2}{*}{ Suicide Risk } & Pre-test & \% & Post-test & \% \\
\hline Low & 1 & 1.7 & 35 & 59.3 \\
High & 58 & 98.3 & 24 & 40.7 \\
\hline & z-value & & p-value & \\
\hline
\end{tabular}

association of Indonesian Psychiatrists (PDSKJI) Jakarta said that social media is one of the factors that trigger a person to commit suicide. Ages 16-24 years have a higher risk of suicide. The suicide rate is directly proportional to the increase in age, and increases at a young age, namely 15-24 years (Riyadi, 2004). It is strengthened by research from Kementerian Kesehatan Republik Indonesia, (2019), which states that suicide is currently the second leading cause of death in adolescents and young adults aged 15-29 years.

The research findings reveal that the majority of students prefer to keep their problems to themselves, and some of them have a history of physical/sexual violence. Student who prefers to keep their problems alone, tends to be introverted, and has physical/sexual abuse traumas, has a higher chance of mental health disorders, to the point that it can result in a person at risk of suicide because a history of physical/sexual violence will result in trauma and affect psychological resilience in dealing with problems. If someone has a problem and feels unable to face it and does not ask for advice, solutions, or motivation from other people, it will add to a heavier burden. If this condition is not addressed, it will cause suicidal thoughts. Humans are created as social beings and need the attention and support of others when facing problems. Alternative solutions and motivation are needed so that he does not feel alone but has attention and help from others in solving/facing life's problems.

Baertschi, Costanza, and Conuto (2018) described personality as a potential determinant of suicidal ideation and attempts. Yusuf, Fitriyasari, and Nihayati (2015) explained that several factors cause suicide, one of which is behaviour and personality disorders. There are four aspects of a closed personality associated with an increased risk of suicide, namely hostility, impulsivity, depression, and hopelessness.

The results of the study found that most of the students attempted suicide, namely passing thoughts with a rare frequency. Suicide is an act that is prohibited by all religions so that the desire to try suicide that comes to students' minds will decrease when they remember God and will appear again when they feel unable to face the problem at hand. The factor of close people or loved ones also plays a role in reducing suicidal thoughts/desires. But what needs to be watched out for is that a history of suicidal thoughts can recur or come back if you do not have the knowledge and skills of problem-solving as well as good coping mechanisms. Spirituality is a tendency to create meaning in life through intrapersonal and transpersonal relationships in overcoming life's 
problems (Yusuf et al., 2017). Shinde and Wagani (2019) explained that thoughts or attempts to commit suicide that have occurred will be the most significant risk factor for the occurrence of repetition of actions in the future, so it is very important to screen students for suicide risk to identify quickly so that efforts can be made to prevent suicide risk as early as possible for students.

The results of pre-test research is that the risk of suicide is high. This is because they do not have problem-solving skills. Research Mcauliffe, Mcleavey, and Fitzgerald (2014) explained that problem-solving skills training provided significant psychological and social improvements and showed a positive treatment effect in the self-harm group. Problem solving training has a positive impact and is proven worthy of self-harm therapy, quality of life and depression (Perry et al., 2019). Social problemsolving therapy was found to provide an additional percent of the variance in Non Suicidal Self Injury (NSSI) predictions (Lucas et al., 2019). Supported by the results of the Lutz et al. (2020), the research study found that problem solving therapy as a psychotherapy intervention reduces the risk of suicide in adults and anxiety disorders. Breitborde, Wastler, Pine, \& Moe's (2021) study showed that improved social problem-solving skills may facilitate suicide reduction.

After conducting spiritual problem-solving interventions via the web, it is found that there is a decreased risk of suicide. Screening found an increase in the number of respondents who said they "never thought about trying to kill themselves". The number of suicidal thoughts in the year saying "never" increased. The majority of students said that they "do not speak of suicidal thoughts to others," and will never attempt suicide again. Spiritual problemsolving interventions via the web provide high motivation to make changes to themselves for the better and have a more adaptive coping mechanism and find ways to solve the problems faced appropriately according to the demands and desires of current students. Motivation is an active impulse so that there is a change in energy in humans that moves to achieve goals or needs. Motivation has a function as a driving force and driving behaviour (Candra et al., 2017). Motivation and learning are two inseparable things. Learning something based on strong motivation will give good results, as it is known learning is the process of acquiring various skills, skills, and attitudes, and learning brings about behaviour change (Muhammad, 2017). In addition to motivation problem-solving skills are also needed. Research from Sarkisian, Van Hulle, \& Goldsmith (2021) found that problem solving research in children was significantly meaningful with the risk of suicidal thoughts. Such problem-solving therapies can improve the prediction and treatment of suicidal ideation in adolescents.

In the results of the evaluation in the counselling session via the web, the respondents said that they prefer web-based interventions because their identity is unknown, they are more flexible in conveying problems, are not ashamed, and can facilitate students who have introverted personalities or have difficulty communicating directly. Intervention conventionally has a weak side, namely the presence of stigma that reduces the interest of respondents to seek solutions to problems/solutions to professionals, so that an alternative solution to problems through web applications is needed. Web applications have the advantage of being more efficient in time, place, and cost. The results of this study are consistent with other studies, namely research Luca, Lytle, and Yan (2019), students prefer to seek mental health assistance online, this type of intervention could be beneficial for students who need services who are afraid to visit mental health centres on campus because of the stigma. An effective way to reduce student distress, and the presence of suicidal thoughts, with a combination of online and conventional services, can be provided. Research from Ballesteros and Hilliard (2016) explained that online counselling has a significant relationship with self-stigma. Problem-solving skills have resulted in systems that are now suitable for chronic mental disorder management, problem solving using technologies such as an application whose operation has more privacy and confidentiality of all information stored in the application, and users can anonymize their identity. Troubleshooting using smartphone apps with self-harm prevention management (Hatcher et al., 2020).

\section{CONCLUSION}

Web-Based Spiritual Problem Solving has been shown to be effective in reducing college students' suicide risk. The interventions were delivered via the web using PowerPoints, inspirational videos, and counselling. It can be used 24 hours and specifically for counselling, two-way communication on the web, and privacy is maintained because of a hidden identity. It is hoped that the researchers will further develop web-based interventions in the prevention of suicide risk in the campus environment.

\section{REFERENCES}

Baertschi, M., Costanza, A., \& Conuto, A. (2018). The Function of Personality in Suicidal Ideation from the Perspective of the Interpersonal-Psychological Theory of Suicide. International Journal of Environmental Research and Public Health, 15, 115. https://doi.org/10.3390/ijerph15040636

Ballesteros, J. L., \& Hilliard, R. C. (2016). U.S.-Based Latina/O College Students' Attitudes toward Online Counseling. International Journal for the Advancement of Counselling, 38(4), 269-285. https://doi.org/10.1007/s10447-016-9271-x

Breitborde, N. J. K., Wastler, H., Pine, J. G., \& Moe, A. M. (2021). Suicidality and social problem-solving skills among individuals with first-episode psychosis participating in Coordinated Specialty Care. Early Intervention in Psychiatry, 15(3), 497- 
504. https://doi.org/10.1111/eip.12967

Candra, I. ., Harini, I. G. ., \& Sumirta, I. . (2017). Psikologi Landasan Keilmuan Praktek Keperawatan Jiwa. Penerbit ANDI.

Hatcher, S., Heisel, M., Ayonrinde, O., Campbell, J. K., Colman, I., Corsi, D. J., Edgar, N. E., Gillett, L., Kennedy, S. H., Hunt, S. L., Links, P., MacLean, S., Mehta, V., Mushquash, C., Raimundo, A., Rizvi, S. J., Saskin, R., Schaffer, A., Sidahmed, A., ... Vaillancourt, C. (2020). The BEACON study: protocol for a cohort study as part of an evaluation of the effectiveness of smartphone-assisted problem-solving therapy in men who present with intentional self-harm to emergency departments in Ontario. Trials, 21(1), 1-16. https://doi.org/10.1186/s13063-020-04424-w

Hidayat, D. R. (2018). Konseling Di Sekolah: Pendekatan-Pendekatan Kontemporer. Pertama. Prenadamedia Group.

Keliat, B. ., \& Pasaribu. (2016). Prinsip dan Praktek Keperawatan Kesehatan Jiwa Stuart (indonesia). Elsevier.

Kementerian Kesehatan Republik Indonesia. (2019). Situasi dan Pencegahan Bunuh Diri. In Pusat Data dan Informasi (pp. 1-10).

Lu, W., Bian, Q., \& Song, Y. (2015). Prevalence and Related Risk Factors of Anxiety and Depression among Chinese College Freshmen. 35(6), 815-822.

Luca, S. M. De, Lytle, M. C., \& Yan, Y. (2019). HelpSeeking Behaviors and Attitudes of Emerging Adults: How College Students Reporting Recent Suicidal Ideation Utilize the Internet Compared to Traditional Resources. Journal of American College Health, 1-8. https://doi.org/10.1080/ 07448481.2018.1539397

Lucas, A. G., Chang, E. C., Li, M., Chang, O. D., \& Hirsch, J. K. (2019). Perfectionism and Social Problem Solving as Predictors of Nonsuicidal Self-Injury in Ethnoracially Diverse College Students: Findings Controlling for Concomitant Suicide Risk. Social Work (United States), 64(2), 165-174. https://doi.org/10.1093/sw/swz005

Lutz, J., Mashal, N., Kramer, A., Suresh, M., Gould, C., Jordan, J. T., Wetherell, J. L., \& Beaudreau, S. A. (2020). A Case Report of Problem Solving Therapy for Reducing Suicide Risk in Older Adults with Anxiety Disorders. Clinical Gerontologist, 43(1), 110-117. 10.1080/07317115.2019.1617378

Mcauliffe, C., Mcleavey, B. C., \& Fitzgerald, T. (2014). Group problem-solving skills training for selfharm: randomised controlled trial. 383-390. https://doi.org/10.1192/bjp.bp.111.101816

Muhammad, M. (2017). Pengaruh Motivasi Dalam Pembelajaran. Lantanida Journal, 4(2), 87. https://doi.org/10.22373/lj.v4i2.1881

O’Brien, P. ., Kennedy, W., \& Ballard, K. . (2013). Keperawatan Kesehatan Jiwa Psikiatrik: Teori \& Praktik (B. Angelina (ed.); Bahasa Ind). EGC.
Osman, Bage, \& Guetierrez. (2001). The Suicide Behaviors Questionnaire-Revised (SBQ-R) Overview. 5, 4-6.

Perry, A., Waterman, M. G., House, A., Wright-Hughes, A., Greenhalgh, J., Farrin, A., Richardson, G., Hopton, A. K., \& Wright, N. (2019). Problemsolving training: Assessing the feasibility and acceptability of delivering and evaluating a problem-solving training model for front-line prison staff and prisoners who self-harm. BMJ Open, 9(10), 1-9. https://doi.org/10.1136/bmjopen-2018-026095

Pieter, H. ., \& Lubis, N. . (2017). Pengantar Psikologi dalam Keperawatan (3rd ed.). PT Kharisma Putra Utama.

Potter \& Perry. (2005). Buku Ajar Fundamental Keperawatan: Konsep, Proses \& Praktek (4th ed.). EGC.

Putri, F. . (2018, September). Dampak Negatif Media Sosial Bisa Picu Seseorang Bunuh Diri. Detikhealth.

Riyadi, Y. (2004). Hubungan antara self esteem dengan kecenderungan bunuh diri pada remaja. Skripsi (tidak diterbitkan). Fakultas Psikologi Universitas Widya Mandala. Surabaya.

Ryantono. (2019). "Mahasiswa S2 UNS Solo Tewas Bunuh Diri, Selama Lima Bulan Terakhir Konsumsi Obat Depresi." Tribun Solo.

Sarkisian, K., Van Hulle, C., \& Goldsmith, H. H. (2021). Persistence During Childhood Problem-Solving as a Predictor of Active Suicidal Ideation During Adolescence. Research on Child and Adolescent Psychopathology, 49(4), 533-543. https://doi.org/10.1007/s10802-020-00726-4

Shinde, F., \& Wagani, R. (2019). Does Spirituality Work as a Buffer in Suicide: A Systematic. 14(2), 249256.

Tsong, Y., Young, J. T., Killer, J. D., \& Takemoto, M. A. (2018). Suicide Prevention Program on a Diverse College Campus : Examining the Effectiveness of a Peer-to- Peer Model Suicide Prevention Program on a Diverse College Campus : Journal of College Student Psychotherapy, 00(00), 1-14. https://doi.org/10.1080/87568225.2018.14347 16

Wolitzky-taylor, K., Lebeau, R. T., Perez, M., Gong-, E., Fong, T., Lebeau, R. T., Perez, M., \& Gong-, E. (2019). Suicide prevention on college campuses : What works and what are the existing gaps? A systematic review and meta-analysis. Journal of American College Health, O(0), 1-11. https:// doi.org/10.1080/07448481.2019.1577861

Yusuf, A., Fitriyasari, R, \&, \& Nihayati. (2015). Buku Ajar Keperawatan Kesehatan Jiwa. Salemba Medika.

Yusuf, Nihayati, \& Iswari, M. . (2017). Kebutuhan Spiritual: Konsep dan Aplikasi dalam Asuhan Keperawatan. (Edisi Pert). Mitra Wacana Media. 